\title{
Rights, Knowledge, and Governance for Improved Health Equity in Urban Settings
}

\author{
Françoise Barten, Marco Akerman, Daniel Becker, \\ Sharon Friel, Trevor Hancock, Modi Mwatsama, \\ Marilyn Rice, Shaaban Sheuya, and Ruth Stern
}

\begin{abstract}
All three of the interacting aspects of daily urban life (physical environment, social conditions, and the added pressure of climate change) that affect health inequities are nested within the concept of urban governance, which has the task of understanding and managing the interactions among these different factors so that all three can be improved together and coherently. Governance is defined as: "the process of collective decision making and processes by which decisions are implemented or not implemented": it is concerned with the distribution, exercise, and consequences of power. Although there appears to be general agreement that the quality of governance is important for development, much less agreement appears to exist on what the concept really implies and how it should be used. Our review of the literature confirmed significant variation in meaning as well as in the practice of urban governance arrangements. The review found that the linkage between governance practices and health equity is under-researched and/or has been neglected. Reconnecting the fields of urban planning, social sciences, and public health are essential "not only for improving local governance, but also for understanding and addressing global political change" for enhanced urban health equity. Social mobilization, empowering governance, and improved knowledge for sustainable and equitable development in urban settings is urgently needed. A set of strategic research questions are suggested.
\end{abstract}

KEYWORDS Urban, Health inequity, Governance, Participation, Intersectoral action, Evidence

\section{INTRODUCTION}

This paper draws on an earlier working paper on Governance for Health Equity in Urban Settings developed within the frame of the Global Research Network on Urban Health Equity. ${ }^{1,2}$ The paper focuses on governance to address the social and environmental determinants of urban health inequities. It outlines the key components of governance and the plausible pathways to urban health inequity. The paper finishes with a discussion on knowledge gaps and suggests a research

Barten is with the Nijmegen Urban Health Group, Radboud University Nijmegen, UMCN, Nijmegen, The Netherlands; Akerman is with the Faculdade de Medicina do ABC, Santo André, Brazil; Becker is with the Centro de Promoção da Saúde, Rio de Janeiro, Brazil; Friel is with the University College London, London, UK; Friel is with the The Australian National University, Acton, Australia; Hancock is with the School of Public Health and Social Policy, University of Victoria, Victoria, BC, Canada; Mwatsama is with the National Heart Forum, London, UK; Rice is with the WHO Regional Office for the Americas, Washington, DC, USA; Sheuya is with the Ardhi University, Dar es Salaam, Tanzania; Stern is with the School of Public Health, University of the Western Cape, Cape Town, South Africa.

Correspondence: Françoise Barten, Nijmegen Urban Health Group, Radboud University Nijmegen, UMCN, Nijmegen, The Netherlands. (E-mail: f.barten@elg.umcn.nl) 
agenda to address the gaps in the evidence base concerning governance and urban health inequity in cities in low-income and middle-income countries (LMICs).

\section{Concepts and Definitions of Governance}

Governance is defined as: "the process of decision-making and the process by which decisions are implemented (or not implemented)." Governance is understood as a dynamic process and structure that is changing over time and is embedded within context (Box 1). Analysis of governance should focus on the actors involved in collective decision-making and implementation processes as well as on the structures established to ensure the effective implementation of the decisions. ${ }^{3}$

Governance is concerned with the distribution, exercise, and consequences of power. $^{4}$ Analysis of the (re)production of power relations in governance is necessary. ${ }^{5}$ Although there appears to be general agreement that the quality of governance is important for development, much less agreement appears to exist on what governance really implies and how it should be used. The ambiguities, dilemmas, and concerns surrounding the concept can be explained by the fact that many developmental agencies have employed the concept for various purposes, in different contexts and to advance their own agendas. ${ }^{6}$ Thus, understanding urban governance from a perspective of power and power relations requires knowledge of the historical, social, and economic processes that have characterized social relations and citizenship in specific local, national, regional, and global contexts (see Figure 1). ${ }^{7}$

Power is a contested landscape and is understood in different ways. Power manifests at the level of agents and at the level of structures in which actors interact, and these multiple levels influence each other. ${ }^{8}$ A multidimensional perspective of social power is based upon the following mechanisms: the possession of superior

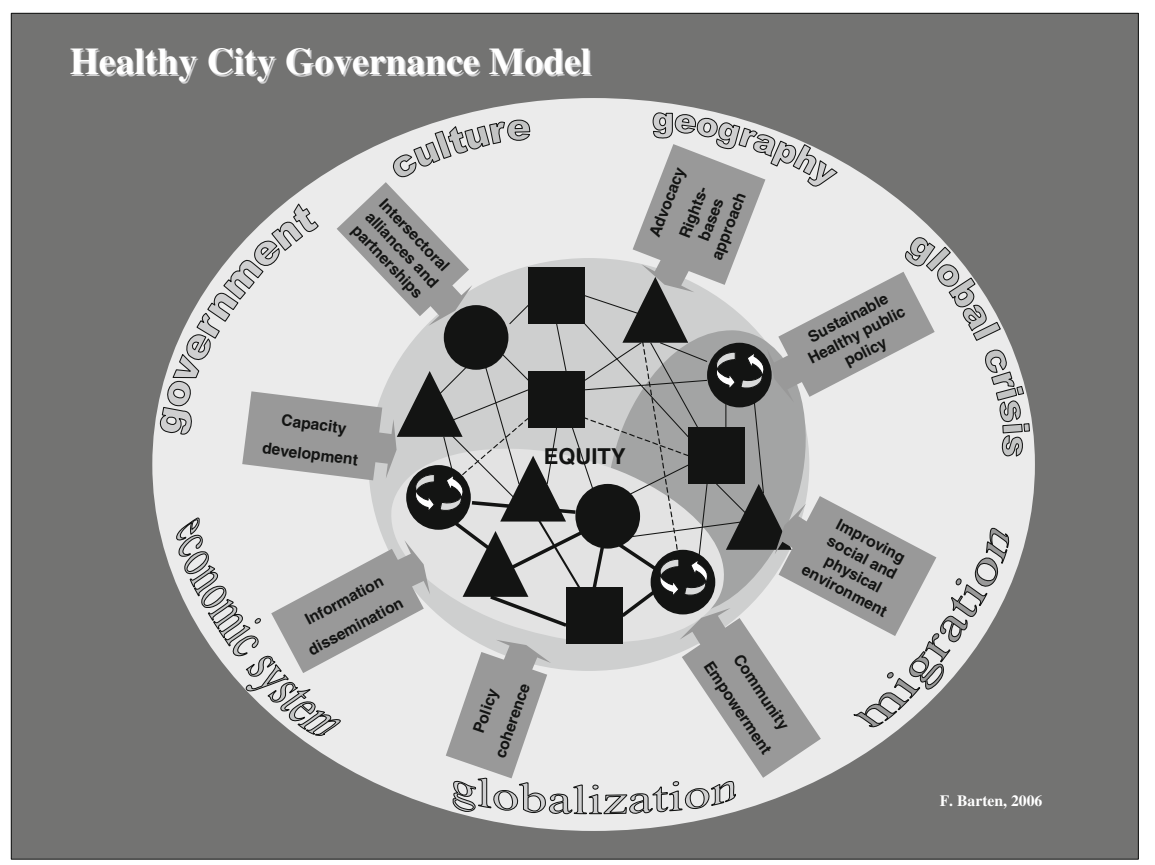

FIGURE 1. Source: Barten F. (2006). The WHO Healthy Settings Approach-a strategy for participatory governance and the promotion of urban health equity at the local level? Background paper developed for the first meeting of the Knowledge Network on Urban Settings, WHO Kobe Centre, Kobe, Japan 
resources, ${ }^{9}$ the control of participation and debate, and the capacity of shaping interests. ${ }^{10}$ The proposal of Swift to move beyond a conventional understanding of power as "power over" toward a more synergistic and relational perspective of power as "power with" seems particularly relevant to the theme of this paper. ${ }^{11}$

\section{BOX 1 Contextualizing urban governance - the example of South Africa}

South Africa has followed the global trend of urban growth. This trend was exacerbated in South Africa by the underdevelopment of rural livelihoods under apartheid in combination with newly established freedom of movement of rural communities. ${ }^{12}$ The result has been an increase in inequity, where wealthy middle-class suburbs back onto poor, overcrowded, informal settlements with few basic facilities. ${ }^{13}$

South Africa provides an interesting example of what promised to be a model of good governance. The new democracy boasts a progressive constitution and pro-equity policies and programs, which encourage effective partnerships and participation. ${ }^{13,14}$ It also has a strong participatory culture dating back to anti-apartheid activism. ${ }^{15}$ Unlike most Sub-Saharan countries, South Africa has the economic potential of a middle-income country. However, these opportunities have been constrained by a global and national policy environment. ${ }^{16}$ Attempts to develop partnerships to tackle the range of problems have had mixed results. While there are many successful examples, there remain inherent tensions within the concept of partnership that limit their effectiveness. These tensions, which are typical of partnerships in all countries, include power differentials such as those among government, NGOs and community partners, bureaucratic systems and divisions within and between organizations and external pressures, including national, donor or commercial priorities. These all have the potential to hinder collaboration, to dominate agendas and to engender mistrust between partners. ${ }^{17}$

\section{Critical Issues}

Although many authors describe governance arrangements, the concept is not always referred to or explained. Our review of the literature confirmed significant variation in meaning as well as in the practice of urban governance arrangements. Governance processes are embedded within context (Box 1), but common characteristics exist across these contexts. First, scale is a particularly important variable since there are some metropolitan regions that develop across country boundaries; and so is level, since supra-local factors and decisions taken by distant and powerful actors can have a profound impact on health inequity within as well as between cities. Decentralization in practice often implied de-concentration, while the rules of the game are still defined at a central level or influenced by global actors. If participation is limited in scope, scale, space, and sphere of influence-and the arena of action does not go beyond a specific neighborhood or single intervention-it might be considered "good" but does not constitute participatory governance for health equity.

Second, governance is a dynamic process, and it is important to acknowledge the fact that governance has been changing significantly over the past two decades. Scholars worldwide, and particularly in the UK and the USA, have started to examine the driving forces and the implications of this shift from government into governance (greater state democratization), one in which government has now become just one of the actors in the policy and decision-making processes. ${ }^{18-21}$ While the Healthy Cities approach in general takes a "governance" rather than a "government-only" approach, it is striking that few evaluations of Healthy Cities have analyzed the implications of this important shift in governance for the conduct of policy, healthy urban planning, and health equity. ${ }^{22,23}$

Third, the city is a contested place. Land tenure, shelter, and economic development are critical issues and this explains the interest in urban regeneration processes, spatial 
justice, and governance. ${ }^{24-27}$ Formal and informal governance arrangements can exist within the space of the city. Actors are changing and new actors are appearing, with increasing roles for civil society and the influences of powerful corporate actors including transnational corporations. ${ }^{28-33}$ Rationalities, structures, power, interests, resources, as well as agendas may differ between actors. ${ }^{34-36}$ What becomes clear is that the different forms of governance, and the way they are exercised, are closely linked to (multi-level) political processes, ${ }^{37}$ with major implications for the health of people residing in different locations.

\section{BOX 2 Water and sanitation: an analytical lens to examine governance and health equity}

Unequal access to water and sanitation has historically been a leading cause of urban health inequalities. Still today, household piped water and sewerage connections are the privilege of a minority in the urban centers of most low- and many middle-income cities. ${ }^{38-40}$ For water, many residents make do with polluted groundwater, distant standpipes, or expensive water sold by local vendors at prices far higher than the official water tariff. For sanitation, open defecation remains common, particularly for children. An important aspect of the link between urban governance and water and sanitation provision lies in the collective nature of the challenge. In economic terms, water and sanitation improvement are quasi-public goods and create the sort of collective action problems conventionally used to justify government action. Indeed, the public health benefits of water and sanitation utilities were used to help justify the creation of public utilities. These utilities performed disappointingly over the course of the $20^{\text {th }}$ century, especially in low-income settings. Governments that are responsive to the needs and health rights of their less-well-off citizens can overcome many of the barriers to improving their urban water and sanitation. A prerequisite for any government-implemented program is a viable financial strategy. The same applies when the government is partnering with private suppliers to provide water and sanitation services. This is not just a question of competence, but very much of governance. ${ }^{41,42}$ Getting the financial and institutional aspect right requires constructive and efficient negotiations between government and civil society groups. Private-public partnerships add another governance dimension to this, as they also require negotiation across the public-private divide. In this case, community organization is likely to be critical, thereby involving another dimension of urban governance.

\section{KEY ELEMENTS OF URBAN GOVERNANCE FOR HEALTH EQUITY}

Participation, partnerships, and community empowerment are critical elements of good governance for addressing the social and environmental determinants of urban health inequities. All three of them are related, and they are a central concern of the Ottawa Charter for Health Promotion, which provides the value base for the Healthy Cities Movement.

\section{Participation}

Participation, according to Stiglitz, ${ }^{43}$ is considered critical to the social transformation necessary for development. Participation can contribute to building ownership and commitment, to shaping avenues for involvement in decision-making processes, and to supporting sustainability of development processes, outcomes, and decisions. Often participation takes place in name only, while in reality professionals, public officials, and bureaucracies manipulate the concept. ${ }^{44}$ In countries characterized by deeply rooted political, social, and economic disparities such as Peru, no straightforward relationship exists between civil society and participation. ${ }^{45}$ The situation of Peru emphasizes the need to take into account the socio-political and historical context and to pay attention to factors such as gender, class, and ethnicity in analyzing the 
meaning of citizenship and participation. Interpretation of a range of research in Brazil and England shows that, "there is a tension between different principles underpinning collective public involvement in health both within and between countries." 46 Participation is integral to social justice in both countries, and while public participation appears to be more inclusive in Brazil than in England, there is still limited evidence that social justice claims have been achieved. Analysis of the participatory dimension of urban governance in Mumbai concluded that it induced double standards of citizenship — new governance arrangements have contributed to empowerment of the middle- and upper-middle class, who have expanded their claims on the city and the political space, while the urban poor have not benefited. ${ }^{47}$

Many innovative experiences exist that have improved participatory governance. In Brazil, for example, there is a movement called "Nossa São Paulo" bringing NGOs, community leaders, private companies and media together to organize an innovative governance framework. It can be difficult, however, to distinguish truly influential and effective governance innovations from superficial changes that have little effect on underlying power relations and merely present a more participatory gloss. Considerations of health equity could provide a means of making such distinctions. Pursuit of urban health equity requires a form of joined-up governance that brings together the health sector and actors in other sectors of municipal, regional, and national governments, that engages with the private for-profit and private non-profit groups; and, vitally, that engages and empowers the citizenry, especially the most disadvantaged and least powerful people and communities.

\section{Partnerships and Intersectoral Action}

Effective partnerships require political and bureaucratic leadership at the highest levels as well as appropriate structures and processes. Critical differences between developed countries and low- and middle income countries (LMICs), e.g., in terms of relative wealth, decision-making autonomy, legal and regulatory framework, and economic complexity, should be acknowledged in order to overcome the real challenges and make partnerships work. Recent research has also begun examining the mismatch between the political rhetoric and the empirical capacity of partnerships. ${ }^{48}$ This UK study concluded that although the notion of partnerships creates a vision of public policy in which everyone seems to benefit by emphasizing efficiency, devolution, and participation, the reality is different: partnerships failed to be inclusive of representative interests; they have reinforced the influence of the central government and facilitated the participation of the private sector in the delivery of public services. The differential capacity of actors to exert power in urban renewal and decision-making has been studied in the context of Santiago, Chile. ${ }^{49}$ In this situation, it was found that representatives from the central government and private investors controlled local redevelopment, while the local government and the people living near the urban renewal project ended up in non-influential positions.

Governance through the formation of public-private partnerships or networks can be effective and has potential to enhance democratic participation in urban policy, but it may also create conflicts and deadlocks and make public governance less transparent and accountable. ${ }^{50}$ A study in Accra, Ghana of waste collection performance from 1985-2000 under two different institutional regimes-from a situation of complete public sector dependence toward increased private sector involvement-found that the public-private mix was more effective for solid waste. The collection rate and disposal improved from $51 \%$ in 1998 to $91 \%$ in 2000 . Unfortunately, these positive results were not sustained once the public-private partnership that lasted for 10 years came to an end. ${ }^{51}$ The emerging Latin American and Brazilian Networks for Just and Sustainable 
Cities are promising as they put a strong focus on the equitable distribution of resources and sustainability. Little research has been conducted on the health equity impacts of these changes in governance.

\section{Community Empowerment for Health Equity}

Different urban communities necessarily require different models of governance to respond to their varying needs. As described above, participation and partnership are essential elements of any model of governance for health equity. Beyond these, health equity depends on the growth of civil society organizations, networks, and movements, and their progressive ability to challenge inequity and push for the installation of equity in the center of all existing and emerging political debates. In Indonesia, community-based approaches have been developed as a response to top-down and authoritarian approaches in order "to increase the community's control over the development process." ${ }^{52}$ Empirical research in Mumbai, India draws attention to the role of civil society organizations in the contested control of urban space and in a context of removal of the urban poor. ${ }^{53}$ An examination of the extent of political participation of the urban poor in Dhaka, Bangladesh in order to ensure access to services demonstrated that collective mobilization of the urban poor in the city of Dhaka has been effective in ensuring the participation of the poor in municipal governance. However, the impact of these initiatives may be limited in terms of securing the national political commitment to urban poverty reduction. ${ }^{54}$ While evaluation of the health equity impact of community action is often limited, there is some evidence for improvements in the conditions of daily living and behavioral risk factors, as seen in the Network of Healthy Communities in Rio de Janeiro (Box 3).

\section{BOX 3 The Network of Healthy Communities of Rio de Janeiro, Brazil}

Launched in 2004, the Rio-de-Janeiro-based Network of Healthy Communities is composed of a mix of community-based organizations (CBOs) and the Centre for Health Promotion (CEDAPS) - an organization working on empowerment and health equity. The 150-member CBOs comprise a mix of Women's and Resident's Associations as well as cultural, religious, and citizen rights groups, which collectively represent a population of over 1.3 million people. The majority of the leaders of these organizations are women (68\%), mostly middle-aged (54\%), and African-Brazilian (75\%). Most use personal resources to develop activities for around 150,000 direct beneficiaries, on issues such as domestic or street violence, provision of cultural and sports activities, prevention of diseases, and poor nutrition. A wide range of local development programs are among the outcomes, including HIV/AIDS prevention centers; distribution of 500,000 condoms per year; training and education; nutrition and physical activity programs; life skills for adolescents; promoting access to health services; and provision of emergency help..$^{55,56}$

\section{KNOWLEDGE GAPS AND RESEARCH NEEDS FOR GOVERNANCE AND URBAN HEALTH INEQUITY}

It appears that researchers have only started to examine the innovations in urban governance in different contexts and the implications for health equity. Many experiences have not yet been identified in the academic literature, especially from cities in LMICs. Most existing evaluations of governance arrangements are incomplete. Critical issues, such as the advent of new powerful actors in the contested space of the city, the power asymmetries as well as the increasing influence of global processes, and external actors on local policy and decision-making are so far neglected.

We need research to understand the interface between international stakeholders and national and local governance and the effect on urban health inequity. Similarly, little is 
known about the interface between national and local government/governance and the impacts of a "whole-of-government" approach to improve health equity.

A coherent conceptual framework of governance and its interrelation with governability is still lacking, and there is a need to understand what participatory urban governance means in theory and practice across different contexts. Corburn ${ }^{57}$ argues that there is a need for new political frames to move toward healthy city planning that includes considerations of population health, a relational perspective of place, an understanding of planning as governance, and relations of power. Bayat ${ }^{58}$ argues that current theoretical perspectives and conceptual frameworks cannot account for the complex impact of the double processes of global restructuring on the contested space of cities and calls for more sophisticated theoretical models. Vianna ${ }^{59}$ points to the importance of historical narratives to better understand urban policy-making processes. Beaumont ${ }^{60}$ urges researchers to assess the importance of socio-political contexts in giving institutions their actual meaning, roles, and functions.

The current emphasis on process at the expense of detailed considerations of health and health equity outcomes is problematic. It can be difficult to distinguish truly influential and effective governance arrangements and practices from superficial changes that have little effect on underlying power relations and to recognize that there are cases that merely present a more participatory gloss without really increasing the capacity to address or ameliorate the social determinants of health. Research on health inequities needs to both draw on and contribute to this analysis.

Reconnecting the fields of urban planning, social sciences, and public healthtransdisciplinary approaches-are essential "not only for improving local governance, but also for understanding and addressing global political change" 57 for enhanced urban health equity. Social mobilization, empowering governance, and improved knowledge for sustainable and equitable development in urban settings is urgently needed.

\section{BOX 4 Key questions for a future research agenda on governance and urban health equity}

- What does participatory governance mean in theory and practice in different contexts?

- How has evidence of health inequalities and inequities been used to identify, implement, and evaluate governance innovations to improve health equity?

- Under what conditions is a health equity perspective more likely to inform public policy?

- How can a health equity discourse influence governance?

- How is urban governance interpreted, organized, and developed in different contexts?

- What are the constraints and possibilities for urban governance to achieve health equity in different contexts?

- What factors/mechanisms enhance governance in ways that promote health equity?

- What are the attributes and impact on health inequity of social networks and movements?

- What is the influence of national governments on local governance, and what are characteristics of national policy that enables and supports governance for health and equity at the local level?

- What is the interface between international stakeholders and national and local governance and how does it affect health equity?

- What are the barriers and assets for meaningful, effective participation and how to overcome/ maximize them?

- To what extent and in which contexts does participation contribute to governance for health equity?

- Which institutions have the capacity - power, resources - to shape policy agendas?

- Why has there been a persistent increase in health inequities within and between urban settings in spite of deepening participation and a variety of innovative governance arrangements?

- What are the challenges and consequences of the increased use of urban governance? To what extent does the municipal government have the capacity to address the underlying and structural determinants of health inequities (or to implement the decisions of partnerships and coalitions)? 


\section{ACKNOWLEDGEMENTS}

This work was made possible through funding provided by the Rockefeller Foundation and undertaken as a contribution to the Global Research Network on Urban Health Equity. The views presented herein are those of the author(s) and do not necessarily reflect the decision, policy, or views of our institutions.

OPEN ACCESS This article is distributed under the terms of the Creative Commons Attribution Noncommercial License which permits any noncommercial use, distribution, and reproduction in any medium, provided the original author(s) and source are credited.

\section{REFERENCES}

1. GRNUHE (2010). Improve urban health equity through action on the social and environmental determinants of health. Final Report of the Global Research Network on Urban Health Equity. http://www.ucl.ac.uk/gheg/GRNUHE/GRNUHEPublication.

2. Barten F, Akerman M, Becker D, Friel S, Hancock T, McGranahan G, Mwatsama M, Rice M, Sheuya S, Stern R (2010). Governance for health equity in urban settings. Working paper. Global Research Network on Urban Health Equity. http://www.ucl.ac. uk/gheg/GRNUHE/GRNUHEPublication.

3. United Nations Economic and Social Commission for Asia and the Pacific. What is Good Governance? Bangkok, Thailand: UNESCAP; http://www.unescap.org/pdd/prs/ProjectActivities/Ongoing/gg/governance.asp (2010). Accessed 7 Sept 2009.

4. Hay C. Political Analysis. Bastingstoke, UK: Palgrave; 2003.

5. Navarro V. The Political Economy of Social Inequalities: Consequences for Health and Quality of Life. Amityville, NY: Baywood; 2000.

6. Hyden G, Court J, Mease K. Making Sense of Government: Empirical Evidence from Sixteen Developing Countries. Boulder, CO: Rienner; 2004.

7. Barten F, Montiel Perez R, Espinoza E, Morales C. Democratic Governance: a fairy-tale or real perspective? Lessons from Central America. Env Urban. 2002; 14(1): 129-145.

8. Clegg S, Courpasson D, Philips N. Power and Organizations. London, England: Sage; 2007.

9. Dahl R. Who Governs. Democracy and Power in an American City. New Haven, CT: Yale University Press; 1961.

10. Gaventa J. Power and Powerlessness: Quiescence and Rebellion in an Appalachian valley. Chicago, IL: University of Chicago Press; 1980.

11. Swift CF. Empowerment: The greening of prevention. In: Kessler M, Goldston SE, Joffe JM (eds). The present and future of prevention. In honor of George W. Albee. 1992. Newbury Park: Sage Publications.

12. De Swardt C, Puoane T, Chopra M, du Toit A. Urban poverty in Cape Town. Env Urban. 2005; 17(2): 101-111.

13. Sanders D, Chopra M. Key challenges to achieving health for all in an inequitable society: the case of South Africa. Am J Public Health. 2006; 96(1): 73-78.

14. Matheka R, Buccus I. The challenge of local government structures in South Africa: securing community participation. Crit Dialogue Public Participation Rev. 2006; 2(1): 11-17.

15. Marais H. South Africa: Limits to Change. Cape Town, South Africa: University of Cape Town; 1998.

16. Chopra M, Sanders D. From apartheid to globalisation: health and social change in South Africa. Hygiea Internationalis. 2004; 4(1): 153-174.

17. Stern R, Green J. Boundary workers and the management of frustration: a case study of two Healthy City partnerships. Health Promot Int. 2005; 20(3): 269-276.

18. Healey P. Collaborative Planning: Shaping Places in Fragmented Societies. New York, NY: Palgrave; 2006. 
19. Kooiman J. Governing as Governance. London, England: Sage; 2003.

20. Pierre J. Reinventing governance, reinventing democracy? Policy Polit. 2009; 37(4): 591-609.

21. Raco M. Governance. London, England: Elsevier; 2009.

22. Barten F, Rovere M, Espinoza E. Salud Para Todos: Una Meta Posible. San Salvador, El Salvador: Ministerio de Salud Publica y Asistencia Social Pueblos Movilizados y Gobiernos Comprometidos; 2010.

23. Hancock T. Healthy, sustainable communities: concept, fledgling practice and implications for governance. Alternatives. 1996; 22(2): 18-23.

24. Baviskar A. Between violence and desire: space, power, and identity in the making of metropolitan Delhi. Int Soc Sci J. 2003; 55(1): 89-98.

25. Marcuse P. From critical urban theory to the right to the city. City. 2009; 13(2): 185-197.

26. Mitchell D. The Right to the City: Social Justice and the Fight for Public Space. New York, NY: Guilford; 2003.

27. Parnell S, Pieterse E. The 'right to the city': institutional imperatives of a developmental state. Int J Urban Reg Res. 2010; 34(1): 146-162.

28. Appadurai A. Deep democracy: urban governmentality and the horizon of politics. Env Urban. 2001; 13(2): 23-43.

29. Bassett K, Griffiths R, Smith I. Testing governance: partnerships, planning and conflict in waterfront regeneration. Urban Studies. 2002; 39(10): 1757-1775.

30. Caldarovic O, Sarinic J. First signs of gentrification? Urban regeneration in the transitional society: the case of Croatia. Sociologija 1 Prostor. 2008; 46(181-182): 369-381.

31. Chu C. The myths and politics of housing in Hong Kong: the controversy over the demolition of the Hunghom Estate. Habitat Int. 2008; 32(3): 375-383.

32. Das AK, Takahashi LM. Evolving institutional arrangements, scaling up, and sustainability: emerging issues in participatory slum upgrading in Ahmedabad, India. J Plan Educ Res. 2009; 29(2): 213-232.

33. Smith L. The murky waters of the second wave of neoliberalism: corporatization as a service delivery model in Cape Town. Geoforum. 2004; 35(3): 375-393.

34. Bevir M. Democratic governance: systems and radical perspectives. Public Adm Rev. 2006; 66(3): 426-435.

35. Cowen D, Bunce S. Competitive cities and secure nations: conflict and convergence in urban waterfront agendas after 9/11. Int J Urban Reg Res. 2006; 30(2): 427-439.

36. Pierre J. Models of urban governance: the institutional dimension of urban politics. Urban Affairs Rev. 1999; 34(3): 372.

37. Van-Naerssen T, Barten F. Healthy cities as a political process. In: Van Naerssen T, Barten F, eds. Healthy Cities in Developing Countries. Lessons to be learned. Saarbrucken, Germany: Verlag fur Entwicklungspolitik; 2002.

38. Heller L. Water and sanitation policies in Brazil: historical inequalities and institutional change. In: Castro JE, Heller L, eds. Water and Sanitation Services. Public Policy and Management. London, England: Earthscan; 2009.

39. Muradian R, Tiwari BN, Shamsuddin AJ, Domenech L. The South Asian Experience: financial arrangements for facilitating local participation in water and sanitation services (WSS) interventions in poor urban areas-lessons from Bangladesh and Nepal. In: Castro JE, Heller L, eds. Water and Sanitation Services. Public Policy and Management. London, England: Earthscan; 2009.

40. Nilsson D, Kaijser A. Discrimination by default: the post-colonial heritage of urban water provision in East Africa. In: Castro JE, Heller L, eds. Water and Sanitation Services. Public Policy and Management. London, England: Earthscan; 2009.

41. McGranahan G, Satterthwaite D. Governance and Getting the Private Sector to Provide Better Water and Sanitation Services to the Urban Poor. London, England: International Institute for Environment and Development; 2006.

42. Costa GM, Costa HS, Dias JB, Welter MG. The role of municipal committees in the development of an integrated urban water policy in Belo Horizonte, Brazil. Water Sci Tcechnol. 2009; 60(12): 3129-3136. 
43. Stiglitz JE. Participation and development: perspectives from the comprehensive development paradigm. Rev Dev Econ. 2002; 6(2): 163-182.

44. Arnstein SR. A ladder of citizen participation. J Am Plann Assoc. 1969; 35(4): 216223.

45. Ávila J. Gobiernos locales, participación y exclusión social en cuatro distritos rurales de Apurímac y el Cusco. Debate Agrario. 2002; 37: 1-21.

46. Barnes M, Coelho VS. Social participation in health in Brazil and England: inclusion, representation and authority. Health Expect. 2009; 12(3): 226-236.

47. Zérah MH. Participatory Governance in Urban Management and the Shifting Geometry of Power in Mumbai. Dev Chang. 2009; 40(5): 853-877.

48. Cardini A. An analysis of the rhetoric and practice of educational partnerships in the UK: an arena of complexities, tensions and power. J Educ Policy. 2006; 21(4): 393-415.

49. Zunino HM. Power relations in urban decision-making: Neo-liberalism, 'technopoliticians' and authoritarian redevelopment in Santiago, Chile. Urban Studies. 2006; 43(10): 1825-1846.

50. Eggerth L. The evolving face of private sector participation in solid waste management. Waste Manag. 2005; 25(3): 229-230.

51. Fobil J, Armah N, Hogarh J, Carboo D. The influence of institutions and organizations on urban waste collection systems: an analysis of waste collection system in Accra, Ghana (1985-2000). J Environ Manage. 2008; 86(1): 262-271.

52. Dasgupta A, Beard VA. Community driven development, collective action and elite capture in Indonesia. Dev Chang. 2007; 38(2): 229-249.

53. Anjaria JS. Guardians of the Bourgeois City: citizenship, public space, and middle-class activism in Mumbai. City \& Community. 2009; 8(4): 391-406.

54. Banks N. A tale of two wards: political participation and the urban poor in Dhaka City. Env Urban. 2008; 20(2): 361-376.

55. David AM, Mercado SP, Becker D, Edmundo K, Mugisha F. The prevention and control of HIV/AIDS, TB and Vector-borne diseases in informal settlements: challenges, opportunities and insights. J Urban Health. 2007; 84(Suppl.1): 65-74.

56. The Knowledge Network on Urban Settings. Our cities, our health, our future: acting on social determinants for health equity in urban settings. The Knowledge Network on Urban Settings; 2007.

57. Corburn J. Toward the Healthy City. People, Places and the Politics of Urban Planning. Cambridge, MA: MIT; 2009.

58. Bayat A. From 'dangerous classes' to 'quiet rebels': politics of the urban subaltern in the global south. Int Sociol. 2000; 15(3): 533-557.

59. Vianna PVC, Elias PE. Health resort, industrial city: urban space and health policy in São José dos Campos, São Paulo, Brazil. Cad Saude Publica. 2007; 23(6): 1295-1308.

60. Beaumont J, Nicholls W. Plural governance, participation and democracy in cities. Int J Urban Reg Res. 2008; 32(1): 87-94. 